\title{
Occupational pensions and social assistance
}

Received: 22nd March, 2001

\section{Bill Birmingham}

After graduating from the University of Manchester, Bill Birmingham worked for 25 years for the Department of Social Security, initially in a local social security office dealing with claims to means-tested benefits, but mainly in the fields of occupational pensions policy and the application of European Community legislation in the social security and pensions field. He subsequently worked for the National Association of Pension Funds as Manager of Benefit Services and Head of Research. He is now a principal consultant with Aktus Consulting Ltd. and has been involved in advising on the Governments of Russia, Kyrgyzstan, Hungary and China on pension development and regulation. He is also involved in the development of international pensions training.

\begin{abstract}
Means tested benefits, including minimum income guarantee, housing benefit and council tax benefit, are payable to bring persons with low incomes up to a specified statutory level and to assist with rent and council tax liabilities. This paper describes current UK means-tested benefits payable to pensioners and outlines the effect on entitlement to such benefits of receipt of an occupational or personal pension. It examines the aggregate income of lower income pensioners and considers whether, and in what circumstances, low-paid workers achieve a net gain from participation in occupational and personal pension schemes. The paper also refers to the impact on means-tested benefits of occupational and personal pensions not claimed.

The paper goes on to examine the Government's proposals for pension credit and their potential impact on low-income pensioners with a small occupational or personal pension. It concludes that the proposals would overcome much of the current disincentive to participation in supplementary pension arrangements by ensuring that those who participate in, and contribute, to such schemes would receive in aggregate higher income than their colleagues who had not joined such a scheme.
\end{abstract}

Keywords: means-tested benefits; minimum income guarantee; housing benefit; occupational pension schemes; pension credit

Bill Birmingham 27 Bannister Close, Langley, Slough SL3 7DP. Tel: $+44(0) 17535444831$; Fax: +44(0) 1753544831 .

\section{Introduction}

The pensions policy of successive British Governments has been to erect an edifice supported by the standard three pillars. The state itself administers a mandatory first-pillar basic pay-as-you-go state retirement pension and encourages workers, employed and self-employed, to make additional provision for their own retirement through either a second pillar employer sponsored occupational pension scheme or a third pillar individual personal pension plan. ${ }^{1}$ Participation in the supplementary second- and third-pillar element has, however, been largely voluntary.

Nevertheless, for employees, but not the self-employed, an element of the supplementary provision has been compulsory, with the pension derived either from the state earnings-related pension (SERPS) or through a contracted-out occupational pension scheme or through an approved personal 
pension plan. The introduction from April 2001 of stakeholder pension schemes has simplified the operation of occupational and personal pension schemes, particularly for middle income employees, but has not altered the fundamental three pillar construction. The replacement of SERPS by the state second pension (S2P) in April 2002 will alter the relative thickness of the respective pillars and amend, especially for lower paid employees, the weight born by each, but it will not change the fundamental structure.

Yet, if the retirement income edifice is supported by the three pillars, it has the additional support of a buttress that supplements the retirement income of low income pensioners. This buttress is provided by the means-tested social assistance consisting of minimum income guarantee and other income related benefits, such as housing benefit and council tax benefit.

This paper examines the relationship between means-tested benefits and occupational and personal pension benefits and considers the impact that the Government's proposals for pension credit will make on that relationship.

\section{Means-tested benefits}

Beveridge, in his recommendations for a post-war benefit system, ${ }^{2}$ recognised the need for some form of means-tested safety net for those who failed to qualify for the new mandatory national insurance benefit regime. However, in his view, the need for such a system would be limited, as the level of contributory benefits would raise the income of most beneficiaries above the means-tested benefit level. His expectations, however, did not come to fruition. Instead, the level of the national insurance retirement pension was set, and has continued, at a level lower than the ceiling for means-tested benefits.

In the last half-century means-tested benefits have been something of a political hot potato. By definition, those eligible have been the poorest members of society. However, memories of the rigid pre-war means test and the perception of such benefits by many as a degrading form of state charity has throughout led to take-up well below the number of those potentially entitled. For successive governments there has been the dilemma of attempting to target extra benefit expenditure on the poorest groups of beneficiaries, who need it most, or to provide less targeted increases, which, although likely to reach those entitled, benefit those who have less need of them. Changes in benefit title - national assistance, ${ }^{3}$ supplementary benefit, ${ }^{4}$ income support ${ }^{5}$ and minimum income guarantee - and changes in beneficiary description (applicant, claimant, client), the inclusion of a statutory reference to entitlement ${ }^{6}$ and changes in the means of payment ${ }^{7}$ have done little to change the public's perception.

At the same time, however, as attempting to increase take-up of means-tested benefits, and from time to time providing higher than retirement pension indexation, successive governments have sought to reduce the numbers entitled to means-tested benefits by encouraging the acquisition of additional retirement income ${ }^{8}$ and the growth of savings. ${ }^{9}$ The introduction of SERPS and the encouragement of occupational and personal pension participation, AVCs and contracting-out have been with the intention of increasing retirement income. Not only does this have the effect of reducing Government expenditure on means-tested benefits - which comes not from national insurance contributions, but general tax revenue - 
but it also reduces the number below what has come to be recognised as the 'poverty level'. (It is perhaps ironic that, by increasing the level of means-tested benefits as part of an exercise to target the poorest pensioners, the actual number of those below the poverty level actually increases.)

The encouragement to employed and self-employed workers to participate in second- and third-pillar pension arrangements has had the effect of creating a trap for lower paid workers who may ultimately find themselves no better off - and in some cases worse off - from contributing voluntarily to a pension scheme than if they had not done so. This is because currently for every extra pound or penny that they receive by way of occupational or personal pension, they have an equivalent reduction in their income support. Many low paid workers could legitimately ask the question, 'Why put away my earnings for a pension, when at the end of the day I will receive no greater retirement income than my workmate who has put nothing away? In each case our income will be made up by income support to the same level.'

Where someone's income is marginally above the income support ceiling, their additional income may lead to a reduction in housing benefit and council tax benefit and a loss of certain free dental and optical treatment subject to means testing.

Where a person would be entitled to an occupational or personal pension if he or she claimed it, but fails to do so, the amount of the pension forgone is itself taken fully into account in determining entitlement for means-tested benefits.

Originally provision was made to enable the first $£ 1$ of a beneficiary's occupational pension to be disregarded for the calculation of means-tested benefits, but the disregard was abolished at the time of the introduction of SERPS (see below). The Government's proposals for pension credit would go some way to alleviating the problem by increasing beneficiaries' net income by $60 \mathrm{p}$ for every additional $\mathcal{E} 1.00$ that they receive by way of pension or savings income.

\section{Means-tested benefits and occupational or personal pensions: The current position}

Receipt of an occupational pension (or personal pension, annuity or other pension arrangement), or entitlement that would arise if a member of an occupational or personal pension scheme claimed the pension, affects the entitlement to, and rate of, means-tested benefits. This applies even where the pensioner or scheme member is not the claimant to the means-tested benefit, but is the claimant's spouse or unmarried partner. The benefits affected include:

- income support

— income-based jobseeker's allowance

- housing benefit

- council tax benefit

- certain NHS charges for dental treatment, glasses and contact lenses.

Receipt of an occupational or personal pension or equivalent also leads to reduction in the rate of, or removal of entitlement to, certain non-means-tested contributory benefits, ie:

- contribution-based jobseeker's allowance

- incapacity benefit, ${ }^{10}$

- where the pensioner is the state benefit claimant's spouse, certain adult dependency increases to benefits, including such increases to retirement pension.

Although receipt of, or entitlement to, 
an occupational or personal pension does not reduce the rate of basic state retirement pension, including Category $\mathrm{B}$ retirement pensions payable to a married woman or widow, receipt by a dependent spouse may reduce dependency increases.

\section{Income support}

The principle of income support (now called minimum income guarantee (MIG) for those above state pension age) is that eligible persons whose income (or the income of whose family) is below a level specified by Parliament are entitled to the benefit. To be eligible for income support claimants must be aged 16 or over and habitually resident in the UK, Channel Islands, Isle of Man or Republic of Ireland and fall within a specified category. So far as is relevant for occupational and personal pensioners, the categories are:

- persons aged 60 and over

- lone parents with a child under 16 living with them

- persons incapable or treated as incapable of work because of sickness

- persons caring for a severely disabled person or a member of their family who is temporarily ill

- disabled persons whose earnings are reduced because of their disability

- persons temporarily looking after another person

— blind persons

- persons who on 6th October, 1996 were aged 50 or over and who had not been in remunerative work for ten years and have not worked since.

\section{Treatment of capital for income support purposes}

Until April 2001 persons with capital and savings (or members of whose family unit in aggregate have capital and savings) amounting to $\mathcal{\&} 8,000(\mathcal{E}, 16,000$ if they are permanently resident in a residential care or nursing home) were ineligible for income support. However, from April 2001, the $£ 8,000$ limit has been increased for persons aged 60 or

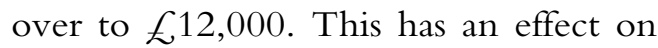
occupational or personal pensioners who commute part of their accrued pension rights to a lump sum. Thus pensioners (or pensioner couples) who commute part of the pension to a lump sum, which with any other savings brings their total capital, if aged 60 or over, to $£ 12,000$ (or if below 60 , to $\mathcal{£} 8,000$ ) will not be eligible for income support, until their capital falls below that level. (Persons who dispose of capital for the specific purpose of claiming income support are treated as retaining the amount disposed of.)

Where persons have capital or savings (excluding the value of the house they live in) of less than the $\mathcal{E}_{12}, 000$ (or $\mathcal{E} 8,000)$ cut-off point, ( $\mathcal{E}, 16,000$ if they are permanently resident in a residential care or nursing home), they are not automatically ineligible for income support. However, if the capital and savings of a claimant (and partner) exceed $\mathcal{E} 6,000$ for persons (or $\mathcal{E}^{3}, 000$ if aged under 60 ), the claimant will be treated as having income of $£ 1.00$ for any part of 250 of capital in excess of the $\mathcal{f}^{6}, 000$ (or $\mathcal{f}^{3}, 000$ ) disregarded. This is known as 'tariff income'. Savings up to $\mathcal{E} 6,000$ ( $\mathcal{K}^{3}, 000$ for persons aged under 60) do not affect entitlement to income support. Examples of the effect of the provision assuming income from capital or savings are shown in Table 1.

From April 2001, therefore, those aged 60 or over who commute their pension to a lump sum to the maximum permitted under Inland Revenue rules are likely to have their lump sum totally disregarded for MIG purposes, assuming 
Table 1.

\begin{tabular}{lcc}
\hline & \multicolumn{2}{c}{ Assumed income } \\
\cline { 2 - 3 } Capital and savings & Persons under 60 & Persons aged 60 and over \\
\hline $3,000.01$ & $£ 1.00$ & 0 \\
$£ 3,999.90$ & $£ 4.00$ & 0 \\
$£ 4,666.67$ & $£ 7.00$ & 0 \\
$£ 5,250.09$ & $£ 10.00$ & 0 \\
$£ 6,000.01$ & $£ 13.00$ & $£ 1.00$ \\
$£ 6,333.67$ & $£ 14.00$ & $£ 2.00$ \\
$£ 8,000.00$ & $£ 20.00$ & $£ 8.00$ \\
$£ 8,250.09$ & Not entitled & $£ 10.00$ \\
$£ 9,333.67$ & Not entitled & $£ 14.00$ \\
$£ 10,760.25$ & Not entitled & $£ 19.00$ \\
$£ 12,000.00$ & Not entitled & $£ 24.00$ \\
\hline
\end{tabular}

no other capital (other than house in which they live), if their

pre-commutation pension rate would have been roughly $£ 2,666$ per year. For those under 60 the equivalent

pre-commutation rate is roughly $\mathcal{E} 1,333$

per year. Similarly, the level at which total disentitlement to MIG applies for those aged 60 or over is at a

pre-commutation rate of roughly $£, 5,333$ per year, but will be $\mathcal{K}^{3,555}$ for those commuting under age 60 .

It is unlikely that there are circumstances under which someone who might otherwise be eligible for income support should restrict the extent of commutation so as to avoid ineligibility. Whereas failure to commute would lead to a higher level of pension being taken into account in calculating entitlement, commutation in cases where the lump sum would not render the claimant automatically ineligible could lead to the lower rate of pension being aggregated with tariff income in determining entitlement.

\section{Level set by Parliament from which income deducted}

Following an Order laid in draft by the Secretary of State, Parliament sets the income level up to which those eligible for income support have their income raised. There is a personal allowance supplemented by premiums applicable in certain prescribed circumstances. A claimant is not entitled to more than one premium (except the severe disability premium and the carer premium, which may be paid in addition to another premium), but is entitled to have whichever applicable premium is the highest taken into account. The personal allowances for a single person aged over 25 and for a couple where at least one member is over 18 for the year $2001 / 2002$ is as shown in Table 2. (There are additional personal allowances where the claimant has dependent children, the rate depending on the child's age.)

The premiums ${ }^{11}$ most likely to be applicable in relation to occupational and personal pensioners and the rates of premium payable for 2000/2001 are shown in Table $3 .^{12}$

The aggregate amounts payable by way of personal allowance and the

Table 2.

\begin{tabular}{ll}
\hline Personal Allowance & \\
\hline Single person aged 25+ & $£ 53.05$ \\
Couple aged 18+ & $£ 83.25$ \\
\hline
\end{tabular}


Table 3.

\begin{tabular}{|c|c|c|c|}
\hline Type of premium & When payable & Single & Couple \\
\hline Disability premium & $\begin{array}{l}\text { Claimant under } 60 \text {, if claimant or partner received } \\
\text { disability living allowance (DVA), disability working } \\
\text { allowance, disabled person's tax credit, long-term rate } \\
\text { incapacity benefit, or severe disablement allowance, } \\
\text { has an invalid vehicle or is registered blind, or if } \\
\text { claimant, but not partner, has been incapable of work } \\
\text { for } 365 \text { days. }\end{array}$ & $£ 22.60$ & $£ 32.25$ \\
\hline \multirow[t]{3}{*}{$\begin{array}{l}\text { Severe disability } \\
\text { premium }\end{array}$} & $\begin{array}{l}\text { 1. A single person lives alone receives attendance } \\
\text { allowance (AA) or middle or higher care component } \\
\text { of DLA, but no-one receives invalid care allowance } \\
\text { (ICA) for them. }\end{array}$ & $£ 41.55$ & \\
\hline & $\begin{array}{l}\text { 2. Claimant and partner both receive AA or middle } \\
\text { care component of DLA, but no-one receives ICA } \\
\text { for them. }\end{array}$ & & $£ 83.10$ \\
\hline & $\begin{array}{l}\text { 3. Claimant has a partner, no-one else lives with them } \\
\text { and } \\
\text { a) both received AA or middle or higher care } \\
\text { component of DLA, but ICA is payable for only } \\
\text { one of them; } \\
\text { b) claimant receives AA or middle or higher care } \\
\text { component of DLA, the partner is blind and } \\
\text { no-one receives ICA for them. }\end{array}$ & & $£ 41.55$ \\
\hline Carer premium & $\begin{array}{l}\text { The claimant or partner is in receipt of ICA or would } \\
\text { have been, but for receipt of another benefit. (A double } \\
\text { premium is payable if both partners receive ICA. }\end{array}$ & $£ 24.40$ & $\begin{array}{l}£ 24.40 \\
(£ 48.80 \text { if } \\
\text { both draw } \\
\text { ICA) }\end{array}$ \\
\hline Pensioner premium & Claimant or partner is aged 60 or over. & $£ 39.10$ & $£ 57.30$ \\
\hline
\end{tabular}

pensioner premium, but excluding any entitlement to the severe disability and carer premiums are therefore as shown in Table 4.

If the single claimant or claiming couple have income below those amounts, they will be entitled to income support, subject to the application of the provisions relating to savings and capital (see above). The current weekly rate of basic Category A state retirement pension is $\mathcal{E}_{72} .50$ and the married woman's rate of category $\mathrm{B}$ retirement pension is f43.40, in each case assuming a contribution record of at least 90 per cent of qualifying years. The age addition of $25 \mathrm{p}$ is included for persons

Table 4.

\begin{tabular}{lll}
\hline $\begin{array}{l}\text { Pension premium with } \\
\text { personal allowance }\end{array}$ & Single & Couple \\
\hline $\begin{array}{l}\text { Personal allowance } \\
\text { and pension premium }\end{array}$ & $£ 92.15$ & $£ 140.55$ \\
\hline
\end{tabular}

aged over 80. If the claimant's income, therefore, is only the basic state retirement pension and the occupational or personal pension - it is assumed that the claimant will have no SERPS where the pension scheme is contracted-out the excess of the personal allowance and pensioner premium over the basic state retirement pension is in accordance with Table 5.

If, therefore, both the claimant and partner are in receipt of a full basic state retirement pension, the claimant will not qualify for income support, except where the conditions for the additional award of a severe disability premium and/or in certain cases a carer premium apply. However, a single person, or a couple where the wife qualifies for a Category $B$ retirement pension on the basis of her husband's national insurance contributions, will, with no other income and not being disqualified under the capital provisions, become eligible for 
Table 5.

\begin{tabular}{llll}
\hline & Single & $\begin{array}{l}\text { Couple - both } \\
\text { Category A }\end{array}$ & $\begin{array}{l}\text { Couple - wife } \\
\text { Category B }\end{array}$ \\
\hline $\begin{array}{l}\text { Personal allowance plus pensioner } \\
\text { premium less basic rate RP }\end{array}$ & $£ 19.65$ & $-£ 4.45$ & $£ 27.65$ \\
& $\begin{array}{l}(£ 19.40 \text { if } \\
\text { aged over 80) }\end{array}$ & $\begin{array}{l}(-£ 4.95 \text { if } \\
\text { both over 80) }\end{array}$ & $\begin{array}{l}(£ 27.15 \text { if } \\
\text { both over 80) }\end{array}$ \\
\hline
\end{tabular}

income support. Where, however, the claimant (or claimant and partner, if a couple) has an occupational or personal pension in excess of $£ 19.65$ (or $£ 27.65$, if a couple), there will be no entitlement to income support.

\section{Deduction of income}

Although certain forms of income may be wholly or partly disregarded for the purposes of income support, state retirement pensions and other social security benefits are taken into account in full in determining entitlement.

Occupational and personal pension payments are also taken into account in full. Accordingly any pension entitlement (and other income) which the claimant (and partner) receives is offset against the aggregate level of personal allowance and applicable premium. Thus, a single pensioner aged 76 with a full basic state retirement pension and an occupational pension amounting to $\mathcal{E} 10.00$ a week and no other income, would receive income support of $\mathcal{E}^{9} 9.65$. The pensioner would also receive housing benefit and council tax benefit.

\section{A disregard on occupational pensions}

Occupational pension payments have not always been taken into account in full. Under the Supplementary Benefits Act $1966,{ }^{13}$ which replaced national assistance by supplementary benefit, the forerunner of income support, the first $£ 1.00$ per week of any occupational pension was disregarded. This disregard continued until shortly before the introduction of SERPS. It was provided to enable those claimants who (or whose employers) had contributed towards providing for their own pension should benefit from having done so. It was also intended to remove any discouragement to individuals acquiring additional pension income. The reason for its abolition was that governments had never disregarded entitlement to another state benefit ${ }^{14}$ and so would not disregard any SERPS entitlement. The then government considered, therefore, that, as SERPS and contracted-out occupational pensions were alternatives, it would be wrong to favour occupational pensioners at the expense of SERPS pensioners by disregarding the first $f 1$ of occupational pensions, but not of SERPS. ${ }^{15}$

The proposals in the Government's consultation paper, 'The Pension Credit', do not attempt to reinstate the disregard in the form that existed from $1967,{ }^{16}$ but (see below) propose to add back 60p in pension credit for every $\mathcal{E} 1$ over the MIG entitlement and abolish tariff income on capital by taking account only of the actual income derived from the capital. If in 1967 the disregard was to encourage individuals to save and make their own provision and to ensure that, if they did so, they would entirely lose the benefit of doing so, the reason for that disregard still exists. The DSS' proposals recognise that principle. However, by granting a pension credit to 
Table 6.

\begin{tabular}{lll}
\hline & Deduction & Entitlement \\
\hline Entitled to income support & None & $£ 150$ \\
Income in excess of IS level $=£ 20$ & $65 \%$ of $£ 20=£ 13$ & $£ 137$ \\
Income in excess of IS level $=£ 50$ & $65 \%$ of $£ 50=£ 32.50$ & $£ 117.50$ \\
Income in excess of IS level $=£ 100$ & $65 \%$ of $£ 100=£ 65$ & $£ 85$ \\
\hline
\end{tabular}

those in receipt of the state second pension (S2P), the Government, while acting equitably, is increasing future unfunded liabilities.

\section{Housing benefit and council tax benefit}

Housing benefit and council tax benefit are means-tested benefits that operate on a similar basis to income support, but apply solely to meet respectively housing costs and council tax. Persons entitled to income support are eligible to have their rent met in full, provided that it is not excessive, and their council tax in full, but in each case there is a reduction if there are non-dependants living in the household. In addition certain persons who do not qualify for income support may qualify for housing benefit and council tax benefit.

The capital and savings level that leads to ineligibility for housing benefit and council tax benefit is currently $£ 16,000$, excluding for council tax benefit the value of the house they live in. ${ }^{17}$ Capital and savings between $\mathcal{E} 6,000$ to $\mathcal{1} 16,000$ ( $£ 3,000$ and $\mathcal{E} 16,000$ for persons aged under 60), is subject to the 'tariff income' provisions as for income support, ie a person is treated as having $£ 1.00$ for every part of $£ 250$ in excess of $\mathcal{E} 6,000$ (or $\mathcal{E} 3,000$ for those under $60)$. Thus persons with a lump sum derived from commutation of between $£ 12,000$ ( $£ 8,000$ if under 60) and $£ 16,000$ would be potentially entitled to housing benefit and council tax benefit even though they would be ineligible for income support.

Persons on low income, not entitled to income support may still claim housing benefit and council tax benefit. Personal allowances and the relevant premiums are the same as for income support. The total income, including tariff income, is deducted from the aggregate personal allowances and premiums. If these exceed the total income, the amount of the rent and council tax are paid, but if not housing benefit and council tax benefit may still be paid, but the amount is reduced by a 'taper'. In the case of housing benefit, this will be the maximum housing benefit reduced by 65 per cent of the amount by which the claimant's income exceeds that amount and in the case of council tax benefit the maximum amount reduced by 20 per cent. Examples of the working of the tapers are shown in Table 6.

A person whose income would be at the level that provides entitlement to income support will need to have income in excess of the aggregate of the personal allowance plus pensioner premium, and the amount of their rent and council tax before they gain from receipt of an occupational pension. Thus a person or couple with housing benefit of $\mathcal{N}^{150}$ and council tax benefit of $£ 20$ a week would need to have aggregate income as shown in Table 8 .

As housing benefit is payable only in relation to rent liability, whether a pensioner lives in rented accommodation 
Table 7.

\begin{tabular}{lll}
\hline & Deduction & Entitlement \\
\hline Entitled to income support & None & $£ 20$ \\
Income in excess of IS level $=£ 20$ & $20 \%$ of $£ 20=£ 4$ & $£ 16$ \\
Income in excess of IS level $=£ 50$ & $20 \%$ of $£ 50=£ 10$ & $£ 10$ \\
Income in excess of IS level $=£ 100$ & $20 \%$ of $£ 100=£ 20$ & Nil \\
\hline
\end{tabular}

Table 8.

\begin{tabular}{lll}
\hline & Single & Couple \\
\hline $\begin{array}{l}\text { Personal allowance and } \\
\text { pension premium }+ \text { HB } \\
\text { of } £ 150+\text { CTB of } 20\end{array}$ & $£ 262.15$ & $£ 310.55$ \\
\hline
\end{tabular}

or is an owner-occupier could have a considerable effect on whether he or she benefits from a relatively low occupational or personal pension.

\section{NHS optical and dental charges}

Persons aged 60 or over obtain free prescriptions and free optical examinations, but have to pay for NHS dental treatment and for glasses unless they are in receipt of income support or have income at a comparable level and no capital or savings in excess of $£ 8,000$. Most people under 60 must also pay for prescriptions and eye tests unless they are in receipt of income support or income-based jobseeker's allowance. In determining, therefore, whether a person is as well off with means-tested benefits as with an occupational or personal pension, there is the added cost of dental treatment and glasses to be taken into account (and the other NHS charges for pensioners aged under 60). ${ }^{18}$

\section{Jobseeker's allowance}

There are two forms of jobseeker's allowance, both available to persons actively seeking work and satisfying other
Table 9.

\begin{tabular}{ll}
\hline $\begin{array}{l}\text { Weekly rate of } \\
\text { occupational pension }\end{array}$ & $\begin{array}{l}\text { Jobseeker's } \\
\text { allowance }\end{array}$ \\
\hline$£ 50$ & $£ 53.05$ \\
$£ 60$ & $£ 43.05$ \\
$£ 75$ & $£ 28.05$ \\
$£ 100$ & $£ 3.05$ \\
\hline
\end{tabular}

conditions in relation to interviews and restrictions following voluntary unemployment, dismissal due to misconduct and non-participation in a trade dispute. The first, contribution-based jobseeker's allowance, is paid for up to 26 weeks for those who satisfy the contribution conditions. The weekly rate is 53.05 . It is not means-tested, but occupational and personal pensions are taken into account in full where they exceed $\mathcal{E} 50$ a week, the excess being deducted from the rate of jobseeker's allowance. ${ }^{19}$ The rate of contribution-based jobseeker's allowance for persons in receipt of an occupational pension is shown in Table 9.

Income-based jobseeker's allowance is means-tested and is payable either after the expiry of the contribution-based jobseeker's allowance or together with that allowance if the rate is less than would be payable under the means test. It operates under analogous provisions as for income support in the calculation of personal expenses and premiums - but in many cases there are no premiums payable. Occupational and personal pensions are treated as income in exactly the same way as for income support. 
Table 10.

\begin{tabular}{|c|c|c|c|}
\hline $\begin{array}{l}\text { Weekly rate of } \\
\text { occupational } \\
\text { pension - single } \\
\text { person }\end{array}$ & $\begin{array}{l}\text { Long-term incapacity } \\
\text { benefit ( } 45 \text { or over } \\
\text { when incapacity } \\
\text { began) }\end{array}$ & $\begin{array}{l}\text { Long-term incapacity } \\
\text { benefit with higher rate } \\
\text { increase (under } 35 \text { when } \\
\text { incapacity began) }\end{array}$ & $\begin{array}{l}\text { Long-term incapacity } \\
\text { benefit with lower rate } \\
\text { increase ( } 35-44 \text { when } \\
\text { incapacity began) }\end{array}$ \\
\hline$£ 85$ & $£ 69.75$ & $£ 84.40$ & $£ 77.10$ \\
\hline$£ 100$ & $£ 62.25$ & $£ 76.90$ & $£ 69.60$ \\
\hline$£ 150$ & $£ 37.25$ & $£ 51.90$ & $£ 44.60$ \\
\hline$£ 200$ & $£ 12.25$ & $£ 26.90$ & $£ 19.60$ \\
\hline$£ 230$ & $£ 0$ & $£ 11.90$ & $£ 4.60$ \\
\hline $\begin{array}{l}\text { Weekly rate of } \\
\text { occupational pension } \\
\text { - claiment with } \\
\text { dependent spouse }\end{array}$ & $\begin{array}{l}\text { Long-term incapacity } \\
\text { benefit ( } 45 \text { or over } \\
\text { when incapacity } \\
\text { began) }\end{array}$ & $\begin{array}{l}\text { Long-term incapacity } \\
\text { benefit with higher rate } \\
\text { increase (under } 35 \text { when } \\
\text { incapacity began) }\end{array}$ & $\begin{array}{l}\text { Long-term incapacity } \\
\text { benefit with lower rate } \\
\text { increase ( } 35-44 \text { when } \\
\text { incapacity began) }\end{array}$ \\
\hline$£ 85$ & $£ 113.15$ & $£ 127.80$ & $£ 120.50$ \\
\hline$£ 100$ & $£ 105.65$ & $£ 120.30$ & $£ 113.00$ \\
\hline$£ 150$ & $£ 80.65$ & $£ 95.30$ & $£ 88.00$ \\
\hline$£ 200$ & $£ 55.65$ & $£ 70.30$ & $£ 63.00$ \\
\hline$£ 250$ & $£ 30.65$ & $£ 45.30$ & $£ 38.00$ \\
\hline$£ 300$ & $£ 5.65$ & $£ 20.30$ & $£ 13.00$ \\
\hline
\end{tabular}

\section{Incapacity benefit}

The Welfare Reform and Pensions Act 1999 extended to incapacity benefit the contribution-based jobseeker's allowance principle of reducing the state benefit to take account of entitlement to occupational or personal pension. Instead, however, of a $\mathcal{E} 1$ for $£ 1$ reduction as with jobseeker's allowance, the reduction is $50 \mathrm{p}$ in the $\mathcal{K}^{1 .{ }^{20}}$ The Government again argues that incapacity benefit is a benefit for persons who would be in work, but for their incapacity, but people with a reasonable occupational or personal pension would not be in work. The effect for a single person and for someone with a dependent spouse is shown in Table $10 .^{21}$

This provision particularly affects those who are forced to retire early and take a pension on grounds of ill health or disability.

\section{Increase for adult dependant}

Although claimants to long-term incapacity benefit and retirement pension can receive an increase in their benefit for a dependent spouse, this increase ceases to be payable if the spouse has earnings of at least the amount of the increase, currently $\mathcal{K}^{43.40 \text {. For this }}$ purpose, the legislation treats occupational and personal pensions as earnings. If, therefore, the spouse's pension is below the rate of the adult dependency increase, but is increased to a level above that rate, the total amount of the increase immediately ceases. Thus a $\mathcal{E} 1$ increase in the spouse's occupational pension could result in a $\mathrm{f}^{40+}$ drop in the beneficiary's state benefit.

\section{The Pension Credit Consultation Paper}

The Pension Credit Consultation Paper acknowledges that current means-tested benefit legislation has a disincentive effect on saving, including through voluntary pension schemes. It recognises that pensioners with limited savings and/or a small occupation or personal pension are little, or no, better off than their colleagues who have not saved during 
their working life. This is because the latter will receive MIG to supplement their state retirement pension and bring their aggregate income up to, or almost up to, the aggregate income of the former who supplement their state retirement pension by an occupational or personal pension or savings. The paper acknowledges that for some pensioners an increase in their occupational pension will currently leave them no better off, as each $\mathcal{E} 1$ increase in the pension will be matched by a $\mathcal{E} 1$ reduction in their MIG.

\section{Treatment of capital}

The paper recognises that, notwithstanding the increase in the capital limits from April 2001 for the over 60s, the principle of denying entitlement to the MIG to someone with medium to high capital, but low income, creates poverty, particularly for those whose capital cannot readily be realised. Similarly, to operate a tariff income provision that assumes a specified level of income from a particular level of capital is artificial and can work to the detriment of those whose actual income from the capital bears no relation to the notional assumed income. Thus the paper proposes that the current tariff income provisions should be replaced by a system that takes account, not of assumed income, but, like the tax system, of the actual income that the pensioner derives from the capital. This would have the effect that where a pensioner invests, for instance, part of the lump sum derived from an occupational or personal pension scheme, but receives no return for a specified period, no income will be taken into account until the additional income is added to the pensioner's account.

The Government is re-examining this proposal as it could act as a disincentive to participation in a pension scheme in comparison with other forms of savings. The pension would be taken into account as income, but no account would be taken of other forms of saving apart from the income that it generates.

\section{The Pension Credit}

The consultation paper proposes the Pension Credit as a means of overcoming the disincentive to save and ensuring that those who do save gain from doing so. The principle behind the Pension Credit is that where medium to low income pensioners with a full basic state retirement pension have savings (including an occupational or personal pension and SERPS (or S2P)) or earnings, their entitlement to $\mathrm{MIG}^{22}$ is increased by a savings credit of $60 \mathrm{p}$ for every $\mathcal{K}^{1}$ income from the second pension, other savings or earnings. The paper states that the provision will be of particular benefit to women pensioners whose income in general is lower than that of male pensioners. An example of the effect of the provision is given in a table in Chapter 4 of the consultation paper for the year 2003 as shown in Table $11 .^{23}$

The principle of savings credit, if introduced, would mean that those low-income pensioners with a small occupational or personal pension would not entirely lose the benefit of their contributions. The disincentive effect for low earners of participating in an occupational pension scheme and for employers with low paid employees of establishing an occupational or stakeholder scheme is ameliorated by the proposal. By bringing in SERPS (or S2P) into the savings credit equation, DSS appears to have overcome the original ground for dispensing with a disregard on occupational pension. ${ }^{24}$

Nevertheless, there are a number of 
Table 11.

\begin{tabular}{|c|c|c|c|c|c|}
\hline \multirow[b]{2}{*}{$\begin{array}{l}\text { Income from } \\
\text { savings, second } \\
\text { pension or earnings }\end{array}$} & \multirow[b]{2}{*}{$\begin{array}{l}\text { Basic state } \\
\text { retirement } \\
\text { pension }\end{array}$} & \multirow[b]{2}{*}{$\begin{array}{l}\text { Aggregate basic state } \\
\text { RP plus savings, } 2 \text { nd } \\
\text { pension, etc. }\end{array}$} & \multicolumn{2}{|l|}{ Pension credit } & \multirow[b]{2}{*}{$\begin{array}{l}\text { Final } \\
\text { income }\end{array}$} \\
\hline & & & $\begin{array}{l}\text { Guaranteed } \\
\text { income top-up }\end{array}$ & $\begin{array}{l}\text { Savings } \\
\text { credit }\end{array}$ & \\
\hline$£ 0.00$ & $£ 77.00$ & $£ 77.00$ & $£ 23.00$ & - & $£ 100.00$ \\
\hline$£ 10.00$ & $£ 77.00$ & $£ 87.00$ & $£ 13.00$ & $£ 6.00$ & $£ 106.00$ \\
\hline$£ 20.00$ & $£ 77.00$ & $£ 97.00$ & $£ 3.00$ & $£ 12.00$ & $£ 120.00$ \\
\hline$£ 30.00$ & $£ 77.00$ & $£ 107.00$ & - & $£ 11.00$ & $£ 118.00$ \\
\hline$£ 40.00$ & $£ 77.00$ & $£ 117.00$ & - & $£ 7.00$ & $£ 124.00$ \\
\hline$£ 50.00$ & $£ 77.00$ & $£ 127.00$ & - & $£ 3.00$ & $£ 130.00$ \\
\hline$£ 60.00$ & $£ 77.00$ & $£ 137.00$ & - & - & $£ 137.00$ \\
\hline
\end{tabular}

issues that the consultation paper leaves unclear and there is a statement that is incorrect. It is not clear what the position is for those pensioners who may have a small occupational or personal pension, but because of a deficient contribution record are not entitled to a basic retirement pension at the full rate. These are likely to be among those who qualify for the MIG. The Government is also examining the impact on long-term incapacity benefit and jobseeker's allowance for those aged between 60 and 65. The proposal would have the somewhat paradoxical effect that receipt of the occupational or personal pension could reduce the entitlement to those state benefits, but the pension credit would be added back because of the reduction.

A comparison of a $\mathcal{E}^{1}$ disregard indexed to $\mathcal{E} 17$ with the Pension Credit proposals in relation to single pensioners and pensioner couples ${ }^{25}$ may be seen in Tables 12 and $13 .{ }^{26}$ The final right hand column compares the effect of a $£, 17$ disregard on occupational pension with the post-credit income as specified in the appendices to the consultation paper.

It will be seen from Tables 12 and 13 that a disregard provides a higher aggregate income for those with the lowest savings or second pension, but leaves those with a higher income worse off. A disregard has the effect of imposing the 'pension trap' not at the lowest level, but at the level at which the amount of the savings or second pension equals the disregard. Hence, although the pension credit leaves the lowest income pensioners worse off than with a $£ 17$ disregard, the pension credit operates on a more equitable basis and avoids reimposing the disincentive effect at a higher level. ${ }^{27}$

\section{The Pension Credit and Housing and Council Tax Benefits}

As described above, the current treatment of income and capital for other means-tested benefits, eg, housing benefit and council tax benefit, are similar, but not identical, to their treatment for income support/MIG. The consultation paper refers to these benefits only in passing when it refers to the cost of the proposals, which will be dependent on the application to these benefits. DSS have hinted that there will be an increase in the requirements for calculating housing and council tax benefits to allow for the savings credit. Failure to do so would result in a minimal net increase in income for most low income pensioners currently in receipt of those benefits. 
Table 12: Single pensioners $£$ per week, 2003-2004

\begin{tabular}{|c|c|c|c|c|c|c|c|c|}
\hline $\begin{array}{l}\text { Orginal } \\
\text { income }\end{array}$ & $\begin{array}{l}\text { Basic Cat } \\
\text { ARP 2002/3 } \\
\text { proposed } \\
\text { rate }\end{array}$ & OP & Disregard & $\begin{array}{l}\text { Net } \\
\text { income } \\
\text { for MIG }\end{array}$ & $\begin{array}{l}\text { Guaranteed } \\
\text { income } \\
\text { top-up }\end{array}$ & $\begin{array}{l}\text { Post } \\
\text { disregard } \\
\text { income }\end{array}$ & $\begin{array}{l}\text { Post- } \\
\text { Credit } \\
\text { income }\end{array}$ & $\begin{array}{l}\text { Excess/ } \\
\text { shortfall } \\
\text { of } \\
\text { disregard }\end{array}$ \\
\hline$£ 77.00$ & $£ 75.50$ & $£ 1.50$ & $£ 17.00$ & $£ 75.50$ & $£ 24.50$ & $£ 101.50$ & $£ 100.00$ & $+£ 1.50$ \\
\hline$£ 80.00$ & $£ 75.50$ & $£ 4.50$ & $£ 17.00$ & $£ 75.50$ & $£ 24.50$ & $£ 104.50$ & $£ 101.80$ & $+£ 2.70$ \\
\hline$£ 85.00$ & $£ 75.50$ & $£ 9.50$ & $£ 17.00$ & $£ 75.50$ & $£ 24.50$ & $£ 109.50$ & $£ 104.80$ & $+£ 4.70$ \\
\hline$£ 90.00$ & $£ 75.50$ & $£ 14.50$ & $£ 17.00$ & $£ 75.50$ & $£ 24.50$ & $£ 114.50$ & $£ 107.80$ & $+£ 6.70$ \\
\hline$£ 92.00$ & $£ 75.50$ & $£ 16.50$ & $£ 17.00$ & $£ 75.50$ & $£ 24.50$ & $£ 116.50$ & $£ 109.00$ & $+£ 7.50$ \\
\hline$£ 95.00$ & $£ 75.50$ & $£ 19.50$ & $£ 17.00$ & $£ 78.00$ & $£ 22.00$ & $£ 117.80$ & $£ 110.80$ & $+£ 6.20$ \\
\hline$£ 100.00$ & $£ 75.50$ & $£ 24.50$ & $£ 17.00$ & $£ 83.00$ & $£ 17.00$ & $£ 117.00$ & $£ 113.80$ & $+£ 3.20$ \\
\hline$£ 105.00$ & $£ 75.50$ & $£ 29.50$ & $£ 17.00$ & $£ 88.00$ & $£ 12.00$ & $£ 117.00$ & $£ 116.80$ & $+£ 0.20$ \\
\hline$£ 110.00$ & $£ 75.50$ & $£ 34.50$ & $£ 17.00$ & $£ 93.00$ & $£ 7.00$ & $£ 117.00$ & $£ 119.80$ & $-£ 2.80$ \\
\hline$£ 115.00$ & $£ 75.50$ & $£ 39.50$ & $£ 17.00$ & $£ 98.00$ & $£ 2.00$ & $£ 117.00$ & $£ 122.80$ & $-£ 5.80$ \\
\hline$£ 116.00$ & $£ 75.50$ & $£ 40.50$ & $£ 17.00$ & $£ 99.00$ & $£ 1.00$ & $£ 117.00$ & $£ 123.40$ & $-£ 6.40$ \\
\hline$£ 120.00$ & $£ 75.50$ & $£ 44.50$ & $£ 17.00$ & $£ 103.00$ & - & $£ 120.00$ & $£ 125.80$ & $-£ 5.80$ \\
\hline$£ 125.00$ & $£ 75.50$ & $£ 49.50$ & $£ 17.00$ & $£ 108.00$ & - & $£ 125.00$ & $£ 128.80$ & $-£ 3.80$ \\
\hline$£ 130.00$ & $£ 75.50$ & $£ 54.50$ & $£ 17.00$ & $£ 113.00$ & - & $£ 130.00$ & $£ 131.80$ & $-£ 1.80$ \\
\hline$£ 134.00$ & $£ 75.50$ & $£ 58.50$ & $£ 17.00$ & $£ 117.00$ & - & $£ 134.00$ & $£ 134.20$ & $-£ 0.20$ \\
\hline$£ 135.00$ & $£ 75.50$ & $£ 59.50$ & $£ 17.00$ & $£ 118.00$ & - & $£ 135.00$ & $£ 135.00$ & $£ 0.00$ \\
\hline
\end{tabular}

\section{Treatment of occupational and personal pension not claimed as being in payment}

There is one area where the current statutory provisions could have a rather strange adverse effect on members of occupational and personal pension schemes. Where legislation provides for an occupational or personal pension to be taken into account as income for determining entitlement to, or the rate of, means-tested or other state benefits, it always also provides for the claimant to be treated as in receipt of any such pension, which, although not in payment, would be payable if the claimant claimed it. ${ }^{28}$ These provisions were introduced to ensure that individuals did not obtain the state benefit, or a higher rate of the benefit, simply by not claiming their occupational or personal pension, thereby subsequently being able to draw the latter at a higher rate as a result of a delayed claim. While the principle of preventing individuals from manipulating the system and thereby maximising the benefit received from both state and occupational scheme may be laudable, it may create problems for scheme members. Some of the effects may be seen as follows:

- A scheme member becomes unemployed or temporarily incapable of work, ${ }^{29}$ or temporarily gives up work to care for a severely disabled or terminally ill relative, soon after age 50 , but with every intention of returning to work, albeit not necessarily with the same employer. He may claim a pension from his occupational pension scheme on the ground of ill health or of early retirement, particularly if made redundant, but the pension would be payable at an actuarially reduced rate. As the occupational pension would be taken into account for the purposes of jobseeker's allowance or incapacity benefit, he may either not claim the pension and potentially have no income or income below the means-tested benefit level, or claim the pension and thus have an actuarially reduced pension for the rest of his life, instead of the pension at the rate payable from normal pension age. He may not wish for tax 
Table 13: Pension couples $£$ per week, 2003-2004

\begin{tabular}{|c|c|c|c|c|c|c|c|c|}
\hline $\begin{array}{l}\text { Orginal } \\
\text { income }\end{array}$ & $\begin{array}{l}\text { Basic Cat } \\
\text { ARP 2002/3 } \\
\text { proposed } \\
\text { rate }\end{array}$ & OP & Disregard & $\begin{array}{l}\text { Net } \\
\text { income } \\
\text { for MIG }\end{array}$ & $\begin{array}{l}\text { Guaranteed } \\
\text { income } \\
\text { top-up }\end{array}$ & $\begin{array}{l}\text { Post } \\
\text { disregard } \\
\text { income }\end{array}$ & $\begin{array}{l}\text { Post- } \\
\text { Credit } \\
\text { income }\end{array}$ & $\begin{array}{l}\text { Excess/ } \\
\text { shortfall } \\
\text { of } \\
\text { disregard }\end{array}$ \\
\hline$£ 123.00$ & $£ 120.70$ & $£ 2.30$ & $£ 17.00$ & $£ 120.70$ & $£ 33.30$ & $£ 156.30$ & $£ 154.00$ & $+£ 2.30$ \\
\hline$£ 125.00$ & $£ 120.70$ & $£ 4.30$ & $£ 17.00$ & $£ 120.70$ & $£ 33.30$ & $£ 158.30$ & $£ 155.20$ & $+£ 3.10$ \\
\hline$£ 130.00$ & $£ 120.70$ & $£ 9.30$ & $£ 17.00$ & $£ 120.70$ & $£ 33.30$ & $£ 163.30$ & $£ 158.20$ & $+£ 5.10$ \\
\hline$£ 135.00$ & $£ 120.70$ & $£ 14.30$ & $£ 17.00$ & $£ 120.70$ & $£ 33.30$ & $£ 168.30$ & $£ 161.20$ & $+£ 7.10$ \\
\hline$£ 138.00$ & $£ 120.70$ & $£ 17.30$ & $£ 17.00$ & $£ 121.00$ & $£ 33.00$ & $£ 171.00$ & $£ 163.00$ & $+£ 8.00$ \\
\hline$£ 140.00$ & $£ 120.70$ & $£ 19.30$ & $£ 17.00$ & $£ 123.00$ & $£ 31.00$ & $£ 171.00$ & $£ 164.20$ & $+£ 6.80$ \\
\hline$£ 145.00$ & $£ 120.70$ & $£ 24.30$ & $£ 17.00$ & $£ 122.00$ & $£ 26.00$ & $£ 171.00$ & $£ 167.20$ & $+£ 3.80$ \\
\hline$£ 150.00$ & $£ 120.70$ & $£ 29.30$ & $£ 17.00$ & $£ 127.00$ & $£ 21.00$ & $£ 171.00$ & $£ 170.20$ & $+£ 0.80$ \\
\hline$£ 151.00$ & $£ 120.70$ & $£ 30.30$ & $£ 17.00$ & $£ 128.00$ & $£ 20.00$ & $£ 171.00$ & $£ 170.80$ & $-£ 0.20$ \\
\hline$£ 152.00$ & $£ 120.70$ & $£ 31.30$ & $£ 17.00$ & $£ 129.00$ & $£ 19.00$ & $£ 171.00$ & $£ 171.40$ & $-£ 0.40$ \\
\hline$£ 155.00$ & $£ 120.70$ & $£ 34.30$ & $£ 17.00$ & $£ 132.00$ & $£ 16.00$ & $£ 171.00$ & $£ 173.20$ & $-£ 2.20$ \\
\hline$£ 160.00$ & $£ 120.70$ & $£ 39.30$ & $£ 17.00$ & $£ 137.00$ & $£ 11.00$ & $£ 171.00$ & $£ 176.20$ & $-£ 5.20$ \\
\hline$£ 165.00$ & $£ 120.70$ & $£ 44.30$ & $£ 17.00$ & $£ 142.00$ & $£ 6.00$ & $£ 171.00$ & $£ 179.20$ & $-£ 8.20$ \\
\hline$£ 170.00$ & $£ 120.70$ & $£ 49.30$ & $£ 17.00$ & $£ 147.00$ & $£ 1.00$ & $£ 171.00$ & $£ 182.20$ & $-£ 11.20$ \\
\hline$£ 171.00$ & $£ 120.70$ & $£ 50.30$ & $£ 17.00$ & $£ 148.00$ & - & $£ 171.00$ & $£ 182.80$ & $-£ 11.80$ \\
\hline$£ 172.00$ & $£ 120.70$ & $£ 51.30$ & $£ 17.00$ & $£ 149.00$ & - & $£ 172.00$ & $£ 183.40$ & $-£ 11.40$ \\
\hline$£ 173.00$ & $£ 120.70$ & $£ 52.30$ & $£ 17.00$ & $£ 150.00$ & - & $£ 173.00$ & $£ 184.00$ & $-£ 11.00$ \\
\hline$£ 174.00$ & $£ 120.70$ & $£ 53.30$ & $£ 17.00$ & $£ 151.00$ & - & $£ 174.00$ & $£ 184.60$ & $-£ 10.60$ \\
\hline$£ 175.00$ & $£ 120.70$ & $£ 54.30$ & $£ 17.00$ & $£ 152.00$ & - & $£ 175.00$ & $£ 185.20$ & $-£ 10.20$ \\
\hline$£ 180.00$ & $£ 120.70$ & $£ 59.30$ & $£ 17.00$ & $£ 157.00$ & - & $£ 180.00$ & $£ 188.20$ & $-£ 8.20$ \\
\hline$£ 185.00$ & $£ 120.70$ & $£ 64.30$ & $£ 17.00$ & $£ 162.00$ & - & $£ 185.00$ & $£ 191.20$ & $-£ 6.20$ \\
\hline$£ 190.00$ & $£ 120.70$ & $£ 69.30$ & $£ 17.00$ & $£ 167.00$ & - & $£ 190.00$ & $£ 194.20$ & $-£ 4.20$ \\
\hline$£ 195.00$ & $£ 120.70$ & $£ 74.31$ & $£ 17.00$ & $£ 172.00$ & - & $£ 195.00$ & $£ 197.20$ & $-£ 2.20$ \\
\hline$£ 200.00$ & $£ 120.70$ & $£ 79.31$ & $£ 17.00$ & $£ 178.00$ & - & $£ 200.00$ & $£ 200.20$ & $-£ 0.20$ \\
\hline$£ 201.00$ & $£ 120.70$ & $£ 80.31$ & $£ 17.00$ & $£ 179.00$ & - & $£ 201.00$ & $£ 201.00$ & $£ 0.00$ \\
\hline
\end{tabular}

or other purposes to receive the pension while subsequently engaged in full time work.

- If in the above case, the member chooses not to draw his pension, it is nonetheless taken into account for state benefit purposes at the actuarially reduced rate. If, when subsequently he begins to draw the pension, it is actually paid for actuarial reasons at a higher rate than has been hitherto taken into account, the state benefit then begins to take it into account at the higher rate. ${ }^{30}$ The member is hit twice. $^{31}$ The current legislation could lead to claimants taking a pension in circumstances, and at a rate, when manifestly it was not in their long term interest to do so.

- A member of a money purchase scheme has the right to draw down some of his accrued pension rights at a level of between 35 per cent or 100 per cent of the annuity rate that he could obtain if he retired. He would like to draw down at 35 per cent, but for state benefit purposes he is treated as drawing down at the 100 per cent rate, whether or not he actually draws down at the rate.

- The scheme permits the member to draw down at a level of between 35 per cent and 50 per cent. As the member would be eligible to claim the full pension, despite his wish to draw down at 35 per cent because of his intention in due course to take a part-time job, he is treated for state benefit purposes as having the pension in full.

- A member has the right to commute to a lump sum payment. To do so would render him ineligible for income support, if the lump sum 
exceeded $£ 12,000$ ( $£ 8,000$ if aged under 60). If the member failed to commute, it is unclear whether account would be taken of the pension at the actual non-commuted rate, or the member would be treated as though he had commuted and so be rendered ineligible for income support.

The Pension Credit consultation paper leaves unclear the impact of the Pension Credit proposals on notional income taken into account for MIG purposes. If it is the DSS' intention to continue to take into account notional entitlement to income, such as an occupational pension, not claimed, the claimant would receive a higher income. A couple of examples show the effect.

\section{Example 1}

A single claimant's income without the unclaimed occupational pension at age 60 is 680.00 . The post-Credit income would be $£ 101.80$, ie, net benefit of $\mathcal{K}^{21.80}$, but if there were no Savings credit, eg because the total income was state benefit, the net benefit would be £20.00. However, the claimant would be entitled to an occupational pension of $\mathcal{E}^{15}$ if s/he claimed it. If it is taken into account, the notional income is $\$ 95.00$

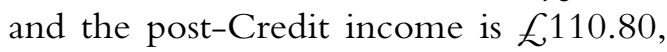
ie, net benefit of $\mathcal{E} 15.80$, which is higher than the occupational pension foregone. In this case taking the occupational pension into account would still mean that DSS was paying less benefit. However, if the claimant then claimed the occupational pension at age 65 , the effect rebounds on the DSS, because the DSS would take account from age 65 of the higher non-actuarially reduced $\mathrm{OP}$ and provide a savings credit on the basis of that higher pension.

\section{Example 2}

A pensioner couple has income without the unclaimed occupational pension of f150. The post-Credit income would be $\mathcal{K}^{170.20}$, ie, net benefit of $\mathcal{E}^{20.20}$, but if there were no savings credit because the couple's income was all state benefit, the net benefit would be $\mathcal{K}^{4} .00$. However, one of the couple would be entitled to an occupational pension of $£_{20}$ if s/he claimed it. If it is taken into account, the notional income is $£ 170$ and the post-Credit income is 12.20 . Thus by taking the notional entitlement into account, DSS would be paying more benefit. (It might be appropriate in such cases to advise occupational or personal pension scheme members not to claim their pension early, as they would be better off if they did not claim it.) DSS have been asked to explain how unclaimed pensions would be treated.

\section{Discretionary increases to occupational scheme benefits}

It is not unknown for administrators of occupational pension schemes to receive requests from scheme pensioners, asking for pension increases not be put into payment. The effect of the increase would be to deny entitlement to income support and certain other means-tested benefits. Pension increases may be of three kinds:

- statutory increases, eg, LPI increases, or RPI to 3 per cent for post-April 1988 GMPs,

- guaranteed increases under scheme rules, e.g. increases of RPI (to $\mathrm{x} \%$ ) for pre-April 1997 service or increases in excess of LPI, and

- discretionary increases (or other enhancement) provided at the discretion of the trustees (or employer). 
As the pensioner has an enforceable right to the first two of the three alternatives, they will automatically be taken into account for state benefit purposes, even if the member seeks to forgo them. There is no automatic right to the third, even if it is the normal practice of the trustees to exercise their discretion to make awards. It might therefore be possible for the trustees to take a decision not to exercise their discretion in specified circumstances, eg, at the member's request where the exercise of the discretion would lead to the member's detriment, but the exercise of discretion would have to be consistent.

\section{The proposed annual calculation}

One welcome provision in the Pension Credit consultation paper relates to the calculation of the pension credit. Currently income support and MIG are calculated on a weekly basis and claimants have a duty to report any change in their circumstances, particularly income and savings, so that account may be taken of the change in determining the following week's entitlement. The value of a claimant's savings may change following transactions in the bank account or a revaluation of a claimant's ISA. The MIG will reduce when the occupational pension is indexed, which may not be at the same time as the annual April uprating of state benefits. Where the entitlement is small, it is possible that the pensioner may qualify for the MIG following the April state benefit uprating, but lose the entitlement when in the autumn the occupational pension is increased, but then requalify for the MIG the following April. Overpayments or underpayments regularly occur because pensioners fail to notify changes.

The consultation paper proposes that like the tax regime entitlement should be determined on an annual basis, except where there is a major change in the pensioner's circumstances. This would avoid the need for reporting of minor changes when they occur during the year and for the entitlement to be adjusted even weekly to take account of such changes. As increases in occupational pensions, whether statutory, discretionary or in accordance with scheme rules, will not, if deemed to be minor changes, require any amendment to the pensioner's pension credit through the year, this will avoid the up and down, or in and out, yo-yo effect where the state and scheme indexations occur at different times of the year. It is not entirely clear whether pension scheme indexation will be treated as a minor change that does not need to be reported and so will allow pension credit entitlement to continue at the same rate throughout the year. If it is treated as a change that does not need to be reported, the time of year at which the pensioner claims pension credit could affect the annual rate. If the claim is made after the state uprating, but before the occupational pension indexation, the rate will be higher than would be the case if the claim were made after the scheme indexation, but before the state uprating. Scheme members might need to be advised when best to claim the pension credit, but a delay to obtain a higher rate could result in some months without means-tested benefit entitlement.

\section{Relationship with occupational pension schemes}

What is the relationship between occupational and personal pension scheme membership and potential entitlement to means-tested benefits and other state benefits, the rate of which is reduced to take account of occupational and personal pensions? What advice, if any, should schemes provide to low-paid earners? 
Where the aggregate rate of occupational and/or personal pension entitlement is less than an individual's potential entitlement to income support and council tax benefit and, where the person lives in rented accommodation, housing benefit, that person would currently gain no extra retirement income from participation in an occupational or personal pension scheme. Indeed, where the scheme is contributory, the person would be depriving himself of current income in the vain expectation of additional retirement income that in practice would not materialise. Similar considerations would apply in respect of AVCs, which scheme members should not pay if they were to gain no net benefit. However, the Pension Credit consultation paper proposals, if implemented, would alleviate the position.

Similar considerations apply to employers. If an employer establishes an occupational pension scheme to reward, recruit and retain staff by providing retirement income for them, is there any benefit to the employer by contributing towards a pension for employees who will gain no net advantage from membership? Can an employer justify to shareholders an expense that benefits neither the company itself, nor the employees? Here again, however, the situation needs to be reconsidered in the light of the Pension Credit proposals.

Even without the introduction of the Pension Credit a number of issues that need to be taken into account before any attempt is made to dissuade an employee from joining an occupational pension scheme or paying AVCs. These are:

- Where the scheme is non-contributory, the employee, but not the employer, may not lose from scheme membership. After retirement, there is no aggregate gain as the pensioner's aggregate income remains at the MIG level, but during the employment there is no reduction in earnings for pension contributions (unless the employee pays AVCs) and the employee will pay lower NI contributions if the scheme is contracted-out.

- If the scheme is a final salary DB scheme, an employee who initially receives low wages may in due course receive incremental pay increases or be promoted within the employer's organisation. The pension accruing during the period of low earnings will thus be based on a far higher salary scale.

- Where a claimant is living with a spouse or unmarried partner, income support and other means-tested benefits are determined on the aggregate income of the couple. This means that, ${ }^{32}$ if one of the couple has income above the income support level, but the other has income less than that level, the couple are unlikely to qualify for means-tested benefits. Accordingly any occupational pension below the income support level payable to the lower income member will not affect any means-tested benefit, but will be net additional income.

- Because some low-paid employees will benefit from scheme membership as regards aggregate retirement income, even if many will not - and those who will benefit are in practice more likely to be women - for an employer to exclude employees with earnings below a specified level from participation in the pension scheme could prove a breach of equal treatment requirements on the basis of indirect discrimination. Where those concerned are part-time employees, it is likely to fall foul also of the EU 
Part-time Workers Directive.

- Recent ECJ and other judgments have implied that part-time workers should have the right to participate in an occupational pension scheme with benefits payable on a pro rata basis in comparison with full-time workers.

To pay pro rata benefits may lead to an unfavourable comparison with basic state retirement pension and SERPS, where those earning above the LEL are not subject to a pro rata deduction.

- Assuming that the employee earns above the LEL, non-participation in the occupational pension scheme does not restrict the employee's state benefit to the basic retirement

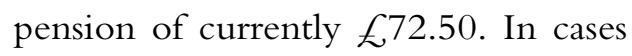
of non-participation in the scheme, the employee must participate in SERPS and from April 2002 the state second pension scheme (S2P).

- Individuals may have gaps in the employment record. As a result their basic state pension may be reduced and there are periods during which they acquire no entitlement to either an occupational or personal pension or to SERPS (or S2P). The problem may be minimised for the basic state pension by the provision of credits for periods of incapacity, caring and jobseeking and by home responsibility protection while looking after children. Although such periods are not covered for SERPS, they will in certain circumstances be covered for S2P.

- The statutory conditions for entitlement to means-tested benefits change over the years as successive governments review their expenditure and social policy. ${ }^{33}$ For instance, when the state pension age has been equalised at age 65 , the then government may decide to withhold pensioner premiums from anyone under 65. Any current advice to low earners as regards the relationship between any potential future occupational or personal pension entitlement and means-tested benefits may prove to be entirely erroneous by the time the individuals concerned retire.

Hence whether any advice should be offered to employers or scheme administrators on advice that they should give to low earning prospective members about choosing whether or not to join the scheme because of the impact on means-tested and other state benefits must be questionable.

\section{Just a British problem?}

It may seem that the issues outlined above are a purely British phenomenon. If, as seems possible, the Chinese Government introduces funded Pillar 1, 2 and 3 schemes, identical issues will arise there.

\section{References}

$1 \mathrm{Nb}$ Self-employed workers are generally able to participate only in personal pension plans.

2 Social Insurance and Allied Services (1942, Cmd 6404).

3 Introduced by the National Assistance Act 1948.

4 Introduced by the Ministry of Social Security Act 1966 (later renamed the Supplementary Benefits Act 1966).

5 Introduced by the Social Security Act 1986.

6 Introduced by the 1966 Act.

7 Payment combined with payment of retirement pension instead of separately.

$8 \mathrm{Eg}$ by the contracting-out provisions of the Social Security Pensions Act 1975, the introduction of COMPS and appropriate personal pensions by the Social Security Act 1986, amendments to the contracting-out conditions under the Pensions Act 1995 and the introduction of stakeholder pensions by the Welfare Reform and Pensions Act 1999.

$9 \mathrm{Eg}$ by the introduction of PEPs, TESAs and ISAs.

10 Under S. 63 of the Welfare Reform and Pensions Act 1999.

11 There are other premiums where there are children in the household.

12 There are provisions to meet costs where the claimant is resident in independent residential care 
or nursing homes or local authority residential accomodation.

13 This was orginally enacted as the Ministry of Social Security Act 1966.

14 There were minor exceptions in relation to certain industrial injuries and war pensions.

15 At the time in 1967 when the 1966 Act provided for the $£ 1$ disregard, the current level of basic state retirement pension was $\mathcal{E} 4.50$ per week.) Had the $£ 1$ disregard continued in existence and been increased from 1967 in line with increases in the basic state retirement pension, it would be worth just almost $\mathcal{K}^{17.00}$ per week from April 2001. This would have enabled occupational pensioners to have the first $£ 70$ of their monthly occupational pension ignored for the purposes of income support.

16 It would be worth about $£ 17$ now, if it had increased in line with increases in the level of the basic state retirement pension.

17 A person eligible for housing benefit would not own the house in which he or she lives.

18 In the past those in receipt of income support or with low income obtained free prescriptions, but other pensioners did not. As prescriptions have been made free to all aged 60 or over, irrespective of their income, entitlement to an occupational or personal pension no longer affects the cost of prescriptions.

19 This level at which occupational or personal pensions were taken into account was increased from $£ 35$ to $£, 50$ a week when jobseeker's allowance replaced unemployment benefit in 1996. Originally the reduction in unemployment benefit to take account of an occupational or personal pension in excess of $£ 35$ a week had been introduced because the then government considered that the majority of people in receipt of such pensions had in effect retired from work and were not in practice seeking new employment. Accordingly, the Government considered that they should not get a benefit aimed specifically at those who had become unemployed through no fault of their own and were now actively seeking work.

20 Originally the Government intended to adopt the same cut-off point of $£ 50$ a week, but during the passage of the Bill, this was increased to $£ 85$.

21 But see next paragraph where spouse has earnings or an occupational or personal pension.

22 including where because of their savings or other income they would have no (or a negative) entitlement to MIG.

23 There is a comprehensive table for single pensioners and pensioner couples in appendices to the consultation paper.

$24 I e$, that it would be unfair to disregard part of the occupational pension of those contracted-out, while taking into account in full the SERPS entitlement of those with no access to an occupational pension.

25 where this is a single disregard and not a disregard for each member of the couple.

26 The basic rate of state retirement pension is given at the 2002/3 rate as specified in the consultation paper, but the post-credit income is taken at the 2003 rate as specified in the paper.

27 If there were a separate disregard for each member of a pensioner couple, the disregard could at all levels of income provide higher aggregate income than the savings credit, but this presupposes that the pension or savings of each partner was above the disregard level. The effect would be different if, from the same aggregate income, the division was such that one member of the couple exceeded the disregard, but the other did not.

28 This presupposes that, if the member claimed, the pension would automatically be put into payment. It does not apply where entitlement, e.g. on early retirement, is dependent on the discretion of the trustees or employer.

29 but unable to work for several months, e.g. following an accident or operation or during chemo- or radio-therapy treatment.

30 If a member of an occupational pension scheme ceases pensionable employment under an occupational pension scheme at age 60 , where the scheme's normal age for a pension with no actuarial deduction is 65 , but the member is entitled to claim the pension, albeit with an actuarial reduction at age 60 , the MIG calculation will take into account the actuarially reduced pension, even if the member does not claim it. If subsequently at age 65 that individual then claims the pension with no actuarial reduction, the IS/MIG calculation takes the pension into account in full, notwithstanding that it would not have been paid at that rate, had it been put into payment at the actuarially reduced rate at 60 , at which rate it has already been taken into account for IS/MIG purposes.

31 This contrasts with the member who actually takes the pension initially at the reduced rate, which, subject to indexation, is the rate permanently taken into account and also with the member who does not need to claim state benefits until the date when the pension comes into payment, who has had no earlier reduction of benefit.

32 In rare cases employers might also find it cheaper to provide scheme benefits than to pay NI contributions at the full (contracted-in) rate, but with the employer's NI contribution threshold, $(£ 87$ a week) now set at a level almost 20 above the LEL ( $f 72$ a week), this is unlikely to be a major consideration.

$33 \mathrm{Eg}$, the abolition of the disregard on occupational pensions and changes in the conditions for entitlement to free prescriptions. 